\title{
A Study on Seed Banking Behaviour of Tribal Farmers of the Andhra Pradesh State, India
}

\author{
A. Srinivas ${ }^{1 *}$, V. Sudha Rani ${ }^{2}$, I. Sreenivasa Rao ${ }^{2}$ and G.E.CH. Vidya Sagar ${ }^{2}$
}

${ }^{1}$ ICAR-Central Tobacco Research Institute, Rajahmundry, Andhra Pradesh-533 105, India

${ }^{2}$ College of Agriculture, Professor Jayashankar Telangana State Agricultural University, Rajendranagar, Hyderabad. 500 030, Telangana, India

*Corresponding author

\section{A B S T R A C T}

\begin{tabular}{|l|}
\hline Ke y w o r d s \\
Seed, Banking, \\
Tribal farmers, \\
Knowledge, \\
Attitude
\end{tabular}

The present study has been initiated focusing on tribal farmers knowledge, attitude and manifested behaviour towards seed banking. The study was conducted in Andhra Pradesh state (erstwhile united Andhra Pradesh). Ex-post facto Research Design was used in the present investigation. Random sampling method was used to select the respondents. A total of 240 respondents were selected for the study from three districts. The results revealed that majority of the tribal farmers $(58.75 \%)$ were found to possess favourable attitude towards seed banking. $47.5 \%$ of the tribal farmers were found to have medium level of knowledge on seed banking activities. They have knowledge on special storage structures like gunny bags, bottle guard shell, pots, mud bins that occupy less space. Majority of the tribal farmers $(62.8 \%)$ had high seed banking behavior. There was a positive and significant relationship between seed banking behaviour of the tribal farmers and the variables viz., age, farming experience, land holding, cosmo politeness, extension contact, training, socio-politico participation, risk orientation, storage facilities and religious belief.

\section{Introduction}

Seed is critical input because without viable seed the survival of their household is endangered. With the modernization of agriculture, agricultural practices and cropping patterns have changed and genetic diversity started getting lost. As a result, the genetic base of traditional seed varieties reduced considerably and several traditional seed varieties are now facing extinction. The main reason for this is the lack of seed banks and seed banking behaviour at village /community level. Farmers, in the process of adopting improved crop cultivars, lost some of their inheritable and accumulated knowledge, innovations and technologies of seed selection, treatment and storage. Considering these issues, promoting the local seed varieties through informal seed distribution systems such as community seed banks/seed banks is the need of the hour in tribal areas. Knowledge on seed banking is required to promote informal seed distribution systems in tribal areas. Very limited research has been taken up in this community seed banks and 
seed banking behavior of farmers in tribal areas. In this context, the present study was contemplated.

\section{Materials and Methods}

The ex-post facto research design was adopted for the study, since the variables chosen for the study have already occurred. Andhra Pradesh was selected purposively for the study. Random sampling method was used to select the respondents. To represent the entire state, three districts from all three regions of the state were selected viz., Adilabad district from Telangana region, Vijayanagaram district from Coastal Andhra region and Kurnool district from Rayalaseema region. Considering the time and resources, only two mandals from each district and four villages from each mandal were selected. Thus making a total of twenty-four (24) villages for the study. From each village, ten respondents were selected for the study. Thus the study constituted a total of 240 respondents.

Knowledge test and attitude scale were developed to measure knowledge level and attitude of framers towards seed banking. The interview schedule was developed for the study. The interview schedule was pre tested with outside the sample area. The data was collected through interview schedule. The collected data was coded, tabulated, analysed. The findings emerged out of the data was interpreted, necessary conclusions and inferences were drawn. Statistical tools like Frequency, Percentage and correlation coefficient was used to analyse the data.

\section{Results and Discussion}

In the present study, seed banking behaviour is operationalised as tribal farmers attitude, knowledge and skill (manifested seed banking behaviour) towards seed banking in terms of seed saving, seed accessibility, seed production, seed storage, use and distribution to others. Hence the variables attitude, knowledge and seed banking behaviour are discussed together under following headings.

\section{Attitude of the tribal farmers towards seed banking}

The study revealed that, the majority of the tribal farmers $(58.75 \%)$ were found to possess favourable attitude towards seed banking. This was followed by $(22.50 \%)$ of the tribal farmers with the neutral attitude, and the remaining tribal farmers $(18.75 \%)$ exhibited unfavourable attitude towards seed banking (Table 1).

The reason for favourable feeling might be due to the habit of seed saving in tribal areas, availability of local seed varieties, low cost of local seed and their preference to eat produces from local seed as it gives more taste when compared to produce from hybrid seeds.

Knowledge of the tribal farmers on different seed banking activities/approaches

The study reveals that $(47.50 \%)$ of the tribal farmers were found under the medium category of knowledge on seed banking activities. The tribal farmers belonging to the low category of knowledge were found $(20.00 \%)$ followed by very low $(15.83 \%)$, high $(10.00 \%)$ and very high (06.67) level of knowledge (Table 2).

The probable reason for this trend is their favourable attitude towards seed banking and traditional practices of seed saving might have resulted in the medium level of knowledge by the majority.

The above findings are in line with the observation of Valeria et al., (2010).

It is evident from the study that, majority of the respondents gave the answer for the best place for storage of harvested seed $(79.17 \%)$ 
followed by purpose of the stored seed (77\%), before storing of seed which operation is required $(74.58 \%)$, what are the different sources of seed collection in your community (70.83\%), name any two indigenous varieties in your community (67.08\%), which seed is healthier to human being and environment $(61.25 \%)$, local seed varieties ensure that good quality seed is always available in tribal areas
$(57.91 \%)$ (Table 3).

\section{Knowledge on seed storage structures}

56.67 per cent of tribal farmers had a medium level of knowledge on storage structures followed by low (30.00\%) and high level of $(13.33 \%)$ storage facilities respectively (Table 4).

Table.1 Distribution of the tribal farmers according to their level of attitude

\begin{tabular}{|c|c|c|c|}
\hline \multirow[t]{2}{*}{ Sr. No. } & \multirow[b]{2}{*}{ Category } & \multicolumn{2}{|c|}{ Respondents $(\mathrm{n}=\mathbf{2 4 0})$} \\
\hline & & Frequency & percentage \\
\hline 1 & Unfavourable (6-15) & 45 & 18.75 \\
\hline 2 & Neutral (16-25) & 54 & 22.50 \\
\hline 3 & Favourable (26-35) & 141 & 58.75 \\
\hline
\end{tabular}

Table.2 Distribution of respondents according to their knowledge level on seed banking activities/approaches

\begin{tabular}{|c|l|c|c|}
\hline \multirow{2}{*}{ Sr. No. } & \multicolumn{1}{|c|}{ Knowledge level } & \multicolumn{2}{|c|}{ Respondents $(\mathbf{n = 2 4 0})$} \\
\cline { 3 - 4 } & & Frequency & Percentage \\
\hline 1 & Very low (6-11) & 38 & 15.83 \\
\hline 2 & Low (12-17) & 48 & 20.00 \\
\hline 3 & Medium (18-23) & 114 & 47.50 \\
\hline 4 & High (24-29) & 24 & 10.00 \\
\hline 5 & Very high (30-36) & 16 & 06.67 \\
\hline
\end{tabular}

Table.3 Distribution of the respondents based on the frequency of respondents giving the correct answer to the knowledge test

\begin{tabular}{|c|c|c|c|}
\hline S.No & Statement & Frequency & Percentage \\
\hline \multicolumn{4}{|c|}{ Fill in the blanks } \\
\hline 1. & $\begin{array}{l}\text { The best source of seed in your community } \\
\text { (Local seed varieties from tribal farmers) }\end{array}$ & 133 & 55.41 \\
\hline 2. & $\begin{array}{l}\text { By using which seed we can conserve genetic material } \\
\text { (local seed varieties) }\end{array}$ & 69 & 28.75 \\
\hline 3. & $\begin{array}{l}\text { In which way the demand for seed can be fulfilled } \\
\text { (community seed banks) }\end{array}$ & 13 & 5.41 \\
\hline 4. & $\begin{array}{l}\text { Fungicide used for seed treatment } \\
\text { (Thiram/Captan @ } 3 \mathrm{~g} / \mathrm{kg} \text { seed) }\end{array}$ & 5 & 02.08 \\
\hline 5. & $\begin{array}{l}\text { Moisture content should be maintained in stored seed } \\
\text { (3-7\% seed moisture content) }\end{array}$ & 62 & 25.83 \\
\hline 6. & Before storing of seed which operation is required & 179 & 74.58 \\
\hline
\end{tabular}




\begin{tabular}{|c|c|c|c|}
\hline & (drying of seed) & & \\
\hline 7. & $\begin{array}{l}\text { The seed security can be achieved through in tribal areas } \\
\text { (community seed banks/village level seed banks) }\end{array}$ & 20 & 8.33 \\
\hline 8. & $\begin{array}{l}\text { Seed exchange with in community members is known as } \\
\text { (community seed banks) }\end{array}$ & 12 & 05.00 \\
\hline \multicolumn{4}{|c|}{ Multiple choices: } \\
\hline 9. & $\begin{array}{l}\text { What is meant by community seed bank } \\
\text { (A place where seed can be saved, accessed and distributed) }\end{array}$ & 4 & 01.67 \\
\hline 10. & $\begin{array}{l}\text { In situ conservation of seed means, conserving the seed in } \\
\text { (natural population) }\end{array}$ & 58 & 24.17 \\
\hline 11. & $\begin{array}{l}\text { Can you give the meaning of individual seed exchange? (seed } \\
\text { will be exchanged with other farmers) }\end{array}$ & 144 & 60.00 \\
\hline 12. & Which is the best seed in the tribal area? (local seed varieties) & 95 & 39.58 \\
\hline 13. & $\begin{array}{l}\text { For which purpose the saved seed can be utilized? } \\
\text { (As seed for next season) }\end{array}$ & 185 & 77.03 \\
\hline 14. & $\begin{array}{l}\text { Products from which seed is healthier to human being and } \\
\text { environment? (local seed varieties) }\end{array}$ & 147 & 61.25 \\
\hline 15. & $\begin{array}{l}\text { Which seed will be available at a lower price? (local seed } \\
\text { varieties) }\end{array}$ & 121 & 50.42 \\
\hline 16. & $\begin{array}{l}\text { In which way seed sovereignty can be achieved? } \\
\text { (local seed varieties) }\end{array}$ & 37 & 15.41 \\
\hline 17. & $\begin{array}{l}\text { Seed accessibility at the community level can be improved } \\
\text { through? (Community seed banks) }\end{array}$ & 15 & 6.25 \\
\hline 18. & $\begin{array}{l}\text { Which is the best source of seed for small and marginal farmers? } \\
\text { (local seed varieties from farmers) }\end{array}$ & 94 & 39.16 \\
\hline 19. & $\begin{array}{l}\text { Sustainable use of genetic resources can be achieved through? } \\
\text { (local seed varieties) }\end{array}$ & 59 & 24.58 \\
\hline 20. & $\begin{array}{l}\text { Seed conservation and exchange at village level can happen } \\
\text { through? (Community seed banks) }\end{array}$ & 14 & 05.83 \\
\hline 21. & $\begin{array}{l}\text { Farmer's dependence on seed companies can be reduced } \\
\text { through? (local seed varieties) }\end{array}$ & 56 & 23.33 \\
\hline \multicolumn{4}{|c|}{ True/False } \\
\hline 22. & $\begin{array}{l}\text { Informal seed distribution system means, seed distribution with } \\
\text { neighbours, friends and relatives without any formal } \\
\text { procedure(True) }\end{array}$ & 71 & 29.58 \\
\hline 23. & $\begin{array}{l}\text { local seed varieties ensure that seed is always available in tribal } \\
\text { areas (True) }\end{array}$ & 139 & 57.91 \\
\hline 24. & $\begin{array}{l}\text { local seed varieties ensure that seed is available at a higher price } \\
\text { (False) }\end{array}$ & 111 & 46.25 \\
\hline 25. & $\begin{array}{l}\text { The community seed bank become lively hood source of for } \\
\text { farmers(True) }\end{array}$ & 05 & 02.08 \\
\hline 26. & $\begin{array}{l}\text { Local seed varieties will not give good yield even in dry land } \\
\text { areas also (False) }\end{array}$ & 07 & 02.91 \\
\hline 27. & Local seed varieties will reduce input cost for cultivation (True) & 84 & 35.00 \\
\hline 28. & Seed treatment necessary for the seed that you use (True) & 34 & 14.16 \\
\hline
\end{tabular}




\begin{tabular}{|c|c|c|c|}
\hline 29. & $\begin{array}{l}\text { Empowerment of farmer's organization can be achieved through } \\
\text { activities like community seed banks (True) }\end{array}$ & 14 & 05.83 \\
\hline 30 & $\begin{array}{l}\text { By using of high yielding varieties indigenous varieties depletion } \\
\text { happen (True) }\end{array}$ & 87 & 36.25 \\
\hline 31 & $\begin{array}{l}\text { Community seed banks can not act as an alternate income } \\
\text { generating activity (False) }\end{array}$ & 18 & 7.5 \\
\hline 32 & $\begin{array}{l}\text { Reason for depletion of seed stock in the villages is use of hybrid } \\
\text { seed (True) }\end{array}$ & 114 & 47.50 \\
\hline \multicolumn{4}{|c|}{ One word answer } \\
\hline 33 & $\begin{array}{l}\text { Indigenous seed variety means? (Farmers saved/produced seed) } \\
\text { Ans: }\end{array}$ & 109 & 45.41 \\
\hline 34 & Please name any two indigenous varieties in your community? & 161 & 67.08 \\
\hline 35 & $\begin{array}{l}\text { What is meant by local seed fairs? (: local seed varieties are sold } \\
\text { by farmers) }\end{array}$ & 58 & 24.16 \\
\hline 36 & $\begin{array}{l}\text { What is meant by farmer's right? (Rights are given to farmers for } \\
\text { conserving the seed) }\end{array}$ & 8 & 3.33 \\
\hline 37 & $\begin{array}{l}\text { What is the difference between the local seed variety and hybrid } \\
\text { seed? (seed produced by cross-pollinated plants artificially). }\end{array}$ & 40 & 16.67 \\
\hline 38 & $\begin{array}{l}\text { What are the consequences of continuous using of hybrid seed } \\
\text { and replacing the local varieties? (Loss of agro biodiversity) }\end{array}$ & 158 & 65.83 \\
\hline 39 & $\begin{array}{l}\text { Which is the best place for storage of harvested seed? (Air } \\
\text { tighten dry container) }\end{array}$ & 190 & 79.17 \\
\hline 40 & $\begin{array}{l}\text { Please mention any one pesticide which will control the storage } \\
\text { pest? (Beta cyfluthrin and silicon dioxide) }\end{array}$ & 12 & 05.00 \\
\hline 41 & $\begin{array}{l}\text { Tell any indigenous practice for rodent control? (rodenticide } \\
\text { baits) }\end{array}$ & 82 & 34.16 \\
\hline 42 & $\begin{array}{l}\text { How is the seed distributed from community seed bank? } \\
\text { (Through seed exchange or seed sale) }\end{array}$ & 15 & 06.25 \\
\hline 43 & $\begin{array}{l}\text { Can you give any activity through which we can conserve agro } \\
\text { biodiversity? (local seed varieties) }\end{array}$ & 41 & 17.08 \\
\hline 44 & $\begin{array}{l}\text { What are the popular sources of seed collection in your } \\
\text { community? (Natural habitats/friends/relatives/community } \\
\text { members, NGOs and govt agencies) }\end{array}$ & 170 & 70.83 \\
\hline 45 & $\begin{array}{l}\text { How can we establish alternate seed supply in tribal areas? } \\
\text { (Community seed banks) }\end{array}$ & 15 & 6.25 \\
\hline
\end{tabular}

Note: Answers are given in brackets.

Table.4 Distribution of respondents according to the Knowledge on storage structures

\begin{tabular}{|c|l|c|c|}
\hline Sr. No. & Storage facilities & \multicolumn{2}{|c|}{ Respondents $(\mathbf{n = 2 4 0})$} \\
\hline & & Frequency & Percentage \\
\hline 1 & Low (2-3) & 72 & 30.00 \\
\hline 2 & Medium (4-5) & 136 & 56.67 \\
\hline 3 & High (6-7) & 32 & 13.33 \\
\hline
\end{tabular}


Table.5 Frequency of respondents according to their knowledge on type of storage structures

\begin{tabular}{|l|l|c|c|}
\hline \multicolumn{2}{|c}{ Type of storage } & Frequency & Percentage \\
\hline S.no & Pots & 79 & 32.92 \\
\hline 2. & Bottle gouard shells & 92 & 38.33 \\
\hline 3. & Bag storage under the roof on wooden sheets & 49 & 20.41 \\
\hline 4. & Bag storage in kitchen/in any other room & 158 & 65.83 \\
\hline 5. & Mud bins & 119 & 49.58 \\
\hline 6. & Underground Pits & 10 & 04.16 \\
\hline 7. & Special storage structures & 5 & 02.08 \\
\hline 8. & Community-based storage godowns & 0 & 0 \\
\hline
\end{tabular}

Table.6 Distribution of respondents according to seed banking behaviour

\begin{tabular}{|c|l|c|c|}
\hline Sr. No. & Seed banking behaviour & \multicolumn{2}{|c|}{ Respondents $(\mathbf{n = 2 4 0})$} \\
\hline 1 & Low (6-13) & Frequency & Percentage \\
\hline 2 & Medium (13-20) & 41 & 17.08 \\
\hline 3 & High (20-27) & 49 & 20.41 \\
\hline
\end{tabular}

Table.7 Relationship between independent variables and seed banking behaviour of the Tribal farmers

\begin{tabular}{|c|l|}
\hline S. No. & Characteristics \\
\hline 1. & Age \\
\hline 2. & Education \\
\hline 3. & Farming experience \\
\hline 4. & Land holding \\
\hline 5. & Social status \\
\hline 6. & Annual income \\
\hline 7. & Cosmopoliteness \\
\hline 8. & Extension contact \\
\hline 9. & Socio-politico participation \\
\hline 10. & Transport facilities \\
\hline 11. & Training received \\
\hline 12. & Storage facilities \\
\hline 13. & Religious belief \\
\hline 14. & Innovativeness \\
\hline 15. & Risk orientation \\
\hline
\end{tabular}

\section{Correlation coefficient (r)}

\begin{tabular}{|l|}
\hline $0.518 * *$ \\
\hline $0.063 \mathrm{NS}$ \\
\hline $0.475 * *$ \\
\hline $0.312 *$ \\
\hline $0.154 \mathrm{NS}$ \\
\hline $0.138 \mathrm{NS}$ \\
\hline $0.225 *$ \\
\hline $0.321 *$ \\
\hline $0.194 *$ \\
\hline $0.018 \mathrm{NS}$ \\
\hline $0.265 *$ \\
\hline $0.249 *$ \\
\hline $0.296 *$ \\
\hline $0.134 \mathrm{NS}$ \\
\hline $0.208 *$ \\
\hline
\end{tabular}

* Significant at 0.05 level of probability

** Significant at 0.01 level of probability NS -Non Significant 


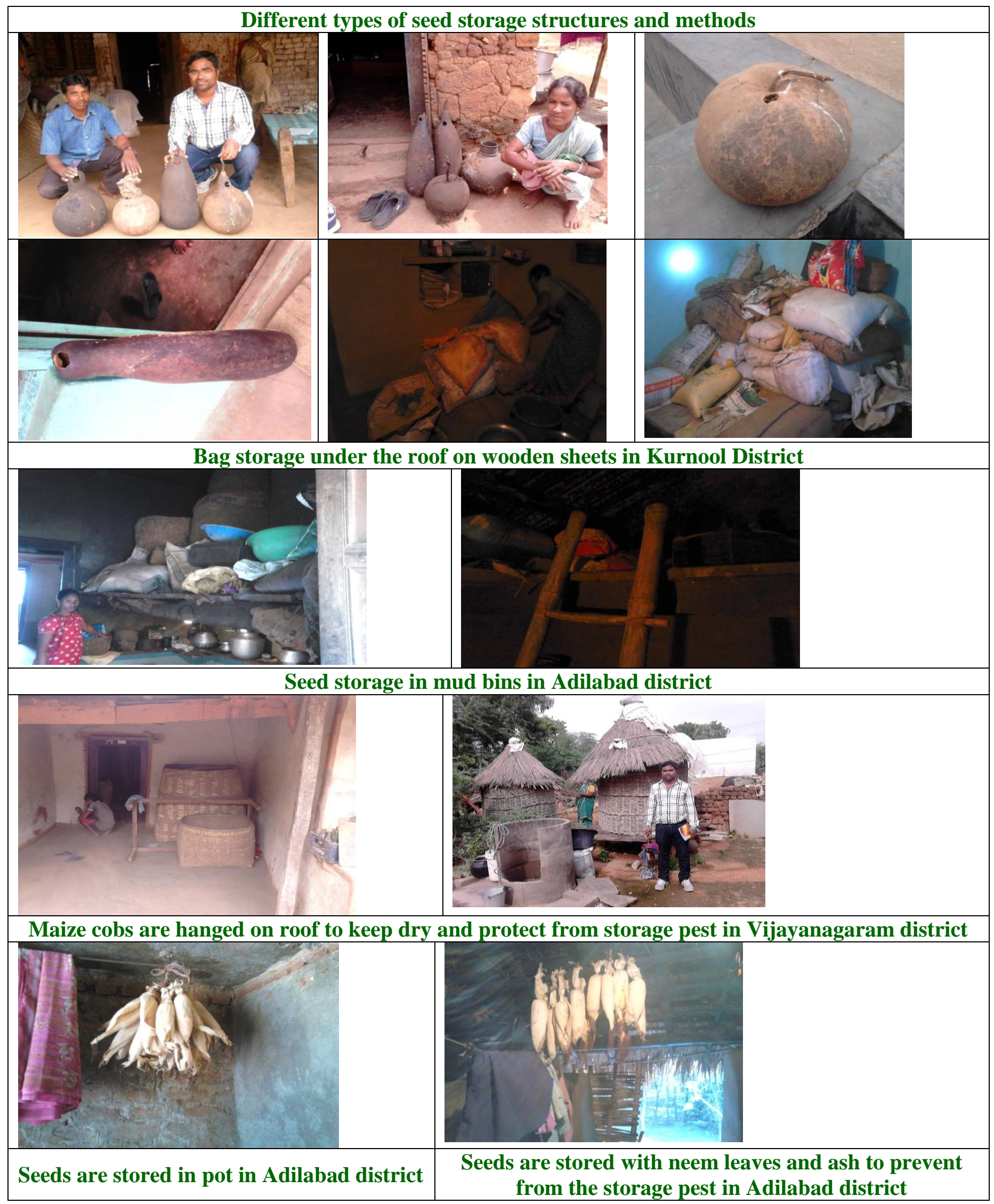



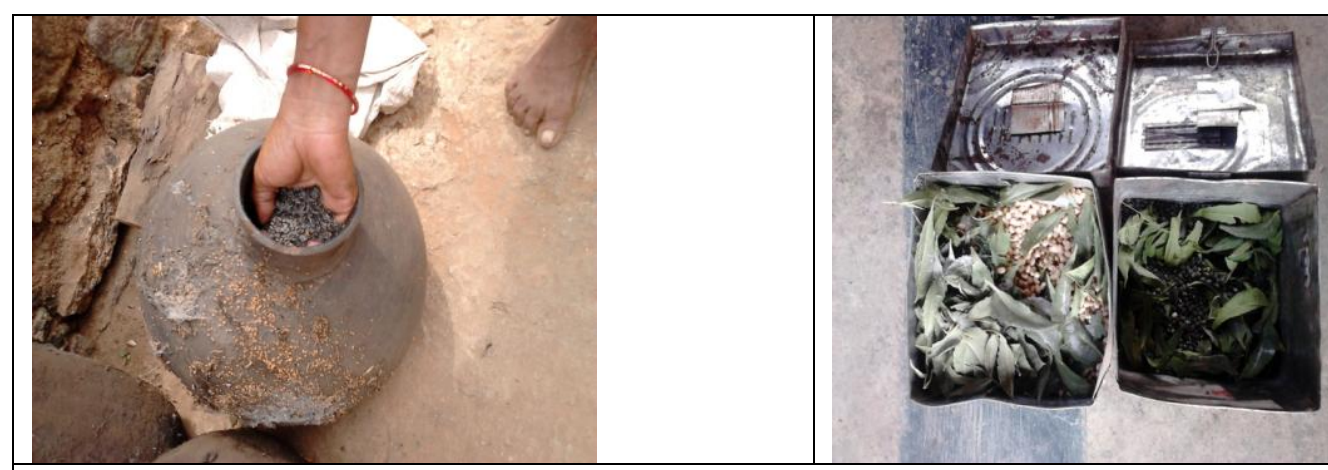

Farmer saved seed of different crops
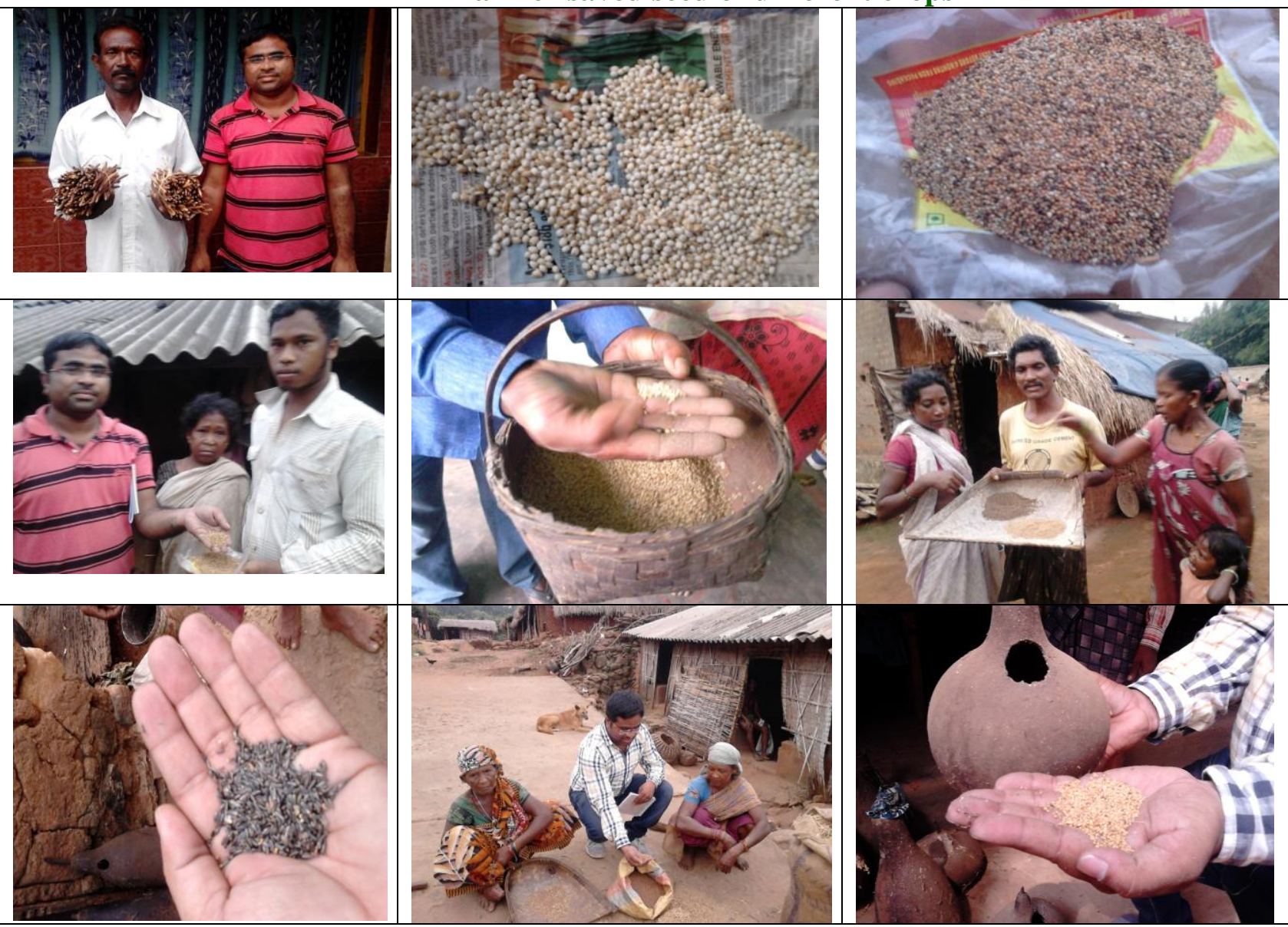

Tribal farmers are selling their saved seed in the local market
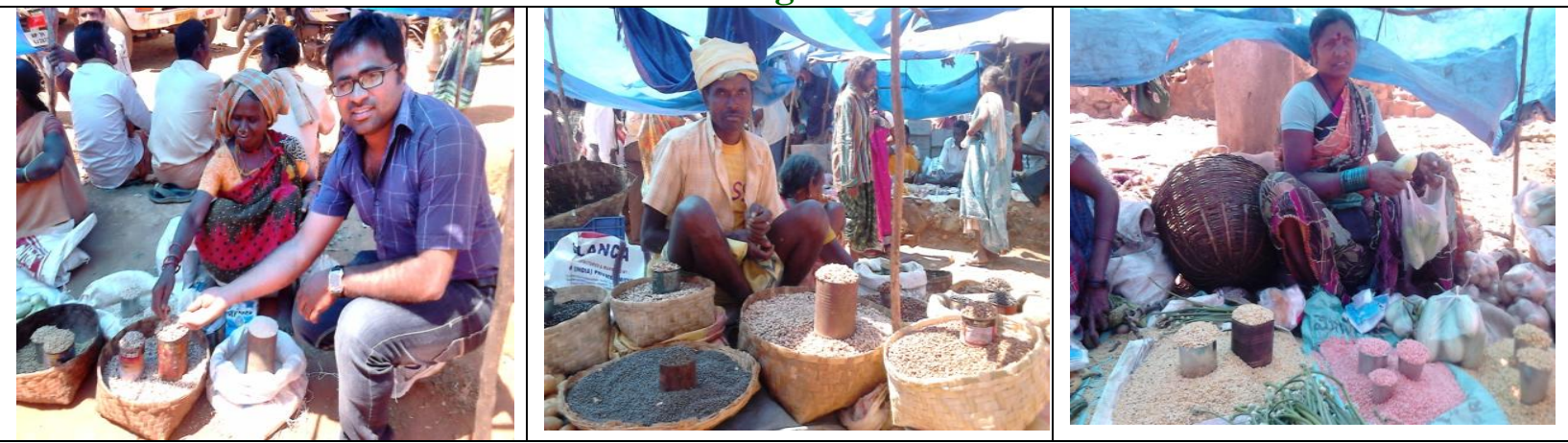
It could be inferred from the results that a great proportion of the tribal farmers had a medium level of knowledge on storage structures (Table 5). They have knowledge on special storage structures like gunny bags, bottle guard shell, pots, mud bins that occupy less space. They don't have knowledge on Community based gowdans. The same result was generated by Ravishankar (2003).

\section{Seed banking behaviour of the tribal farmers}

Seed banking behaviour in manifested form is studied in terms of seed accessibility, seed production, seed storage, use and seed distribution to others.

It was evident from Table 6 that 62.08 per cent respondent had high seed banking behaviour, followed by medium $(20.41 \%)$ and low $(17.08 \%)$ seed banking behaviour respectively.

This is due to non-availability and the high cost of HYVs, the habit of seed saving in tribal areas, availability of local seed varieties, low cost for local seed and their preference to food habit from local seed as it gives more taste when compared to produce from hybrid seed.

It is revealed from the Table 7 that, there was a positive and significant relationship between seed banking behaviour of the tribal farmers and the variables viz., age, farming experience, land holding, cosmo politeness, extension contact, training, socio-politico participation, risk orientation, storage facilities and religious belief

As the seed banking is traditional and old practice, hence the variables age and farming experience were positively and significantly related to the seed banking behaviour of the tribal farmers. Because the older farmers are more traditional. The positive and significant relationship was observed between the variables land holding and seed banking behaviour. This might be due to high input seed cost. The bigger the farm size more input cost is required. Hence the tribal farmers are using the own seed instead of purchasing seeds. The continuous guidance provided by the extension personnel enhances knowledge on recommended technologies in the farming. Hence, the variables extension contact was positively and significantly related with the seed banking behaviour of the tribal farmers. The positive and significant relationship was observed between the variables cosmo politeness and seed banking behaviour of the tribal farmers. This can be justified based on the fact that if the individual is more exposed to the society he can take up the practice of seed banking involving seed collection, production, saving, use and distribution/exchange with others.

Training received by a farmer sharpens the hidden skills and acts as a medium to imbibe any new knowledge or skill in a given profession. Hence, these variables were positively and significantly related the seed banking behaviour of the tribal farmers. Saving and maintaining local seed involves risk of germination. Hence the variable risk orientation was positively and significantly related with the seed banking behaviour of the tribal farmers. If the tribal farmers were having enough storage facilities then only he can save or store the seed. Hence the variables storage facilities were positively and significantly related to the seed banking behaviour of the tribal farmers. Tribal farmers have more faith on god that is why they follow the advices of local religious priest in selecting the seed and other practices of seed saving are traditional. This might be one reason for positive significant association between religious belief and seed banking behaviour of tribal farmer's. 
Activities studied under seed banking behaviour of farmers do not demand high cost, complex technical knowledge in terms of education and innovativeness. Probably because of this the association of seed banking behaviour of farmers was found nonsignificant with variables viz., transport facilities, education, innovativeness, social status and annual income

To increase the seed banking behaviour in tribal areas, to produce and conserve enough quantity of quality traditional seed varieties, improved seed varieties involvement key stakeholders viz., Tribal farmers, extension officers, research organisations and policy makers is essential. Because they are key role players in promoting and maintaining seed banks in tribal areas. Tribal farmers could know the importance of seed banks. They could form Farmers Interest Groups. They should Establish Community seed banks. They need to maintain the adequate amount of quality seeds. Policy makers should establish a cooperative mechanism between the government, private sector and NGO's at all levels.

They should provide financial support for establishment community seed banks. Integration of the informal and formal seed distribution systems is required in order to scaling up. Extension Officers should popularise of seed banks/community seed banks and establishment of the same. They could provide information on available local varieties and seed bank management. Research organisations should conduct research on low-cost quality seed production technologies suitable for tribal areas.

\section{Acknowledgement}

Authors are highly thankful to tribal farmers of the study area for providing information on seed banking.

\section{References}

Kalaskar, A.P., Raut, U.S and Kapse, P.S. 2008. Characteristics of tribal farmers and their relationship with knowledge and adoption of ITK. Agriculture Update, 3 (3\&4): 358-361

Modem Ravikishore and B. Seema. 2017. A Scale to Measure Attitude of Extension professionals towards technology dissemination system of State Department of Agriculture. Indian Research Journal of Extension Education: 17 (1).

Njingulula, P., Wimba, M., Musakamba, K.F., Masuki, M., Katafiire, M., Ugen and Birachi, E. 2014. Strengthening local seed systems within the bean value chain: experience of agricultural innovation platforms in the democratic republic of Congo. African Crop Science Journal. 22(4): 1003 - 1012.

Pandravada, S.R., Sivaraj, N., Sunil, N., Jairam, R., Prasanthi, Y., Chakrabarty, S.K., Ramesh, P., Bisht, I.S and Pareek, S.K. 2013. Sorghum landraces patronized by tribal communities in Adilabad district, Andhra Pradesh. Indian Journal of Traditional Knowledge.12 (3):465-471.

Ranjay, K.S., Bhowmik, S.N and Pandey, C.B. 2011. Biocultural diversity, climate change and livelihood security of the Adi community: Grassroots conservators of eastern Himalaya Arunachal Pradesh. Indian Journal of Traditional Knowledge. 10(1):39-56.

Ravishankar, T. Traditional knowledge and conservation of biodiversity for sustainable livelihoods by tribal communities in southern India. Paper submitted to the XII World Forestry Congress, 2003, Quebec City, Canada.

Shantanu Rakshith and Gyanendra Sharma. 2017. Development of a scale to measure teachers' attitude towards use 
of educational technology in class room instruction. Indian journal of extension education: 53(3): 72-76.

Smith Mishra, Chowdary, S.S and Arivudai, $\mathrm{N}$ and Ambi, V. 2012. Strengthening of traditional paddy seed selection practices of tribal farm families with improved knowledge and skill in koraput district, Odisha. Indian journal of traditional knowledge.11 (3): 461470.
Swathi, G., Vasantha, R and Kiran, S. 2013. Attributes of Agro biodiversity (landraces) as Perceived by Tribal Farmers of Visakhapatnam District. Mysore J. Agric. Sci., 47 (4): 822-827.

Valeria, L., Singh, M.K., Rekha, S and Kudada, N. 2010. Indigenous Technology of tribal farmers in Jharkhand. Indian Journal of Traditional Knowledge. 9(2): 261-263.

\section{How to cite this article:}

Srinivas, A., V. Sudha Rani, I. Sreenivasa Rao and Vidya Sagar, G.E.CH. 2018. A Study on Seed Banking Behaviour of Tribal Farmers of the Andhra Pradesh State, India. Int.J.Curr.Microbiol.App.Sci. 7(01): 2023-2033. doi: https://doi.org/10.20546/ijcmas.2018.701.244 